\title{
HENDERSON THE RAIN KING I: THE LAND*
}

Sigrid Renaux**

"Un paysage est un état d'âme".
Gaston Bachelard

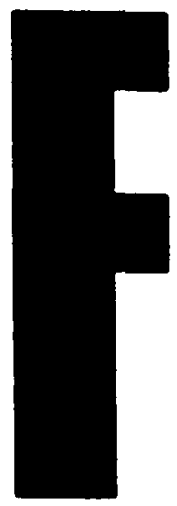

rom America's chaotic reality to "the magic never-land of Africa"':

The setting of Henderson the Rain King*** is as multi-leveled and polyvalent as the other elements of the novel, such as plot, characters, style. America and Africa, respectively in the background and foreground of the narrator's consciousness, interact in his mind in such a way that, while in America (Chapters I to IV), Henderson is telling the reader all the time the reason why he is going to Africa, and while in Africa

* This article corresponds to Chapter I of my Ph.D. dissertation "Bellow's Carnivalistic Vision of the World in Henderson the Rain King" presented at the University of Sảo Paulo in March, 1978. The dissertation examines Bellow's novel by way of M. Bakhtin's Problems of Dostoevsky's Poetics, in which he examines, among other aspects, the carnivalization of literature, the Menippean satire and polyphony. 
(Chapters V to XXII), America has never completely left his subconscious.!

Bellow starts chapter I with Henderson asking the reader: "What made me take this trip to Africa? There is no quick explanation" (7). Again, he starts chapter III with Henderson saying: "And now a few words about my reasons for going to Africa" (21); he concludes this idea by having Henderson ask at the very start of chapter IV: "Is it any wonder I had to go to Africa?" (30).

Besides these and other direct references to the future foreground (in the sense of the action taking place there) of the novel, there are subtle references all over these first four chapters to other aspects linked with Africa, both Biblical and mythical: Daniel's prophecy to King Nebuchadnezzar - "They shall drive thee from among men, and thy dwelling shâll be with the beasts of the field" (22); the association with Ulysses, who got lost in "the sinking softness" of the Mediterranean, "as the sirens sang" (23); the colored foundling Henderson's daughter Ricey has brought home and towards whom he feels "like the Pharaoh at the sight of little Moses" (34). These references prepare us for something more than a simple sightseeing trip which Henderson takes to film Africa, in the company of his newly-wed friends Charlie Albert and his wife.

Thus, linked with the actual trip that Henderson takes to Afri$\mathrm{ca}$, there are connotations from the beginning of the novel onwards, that point to a polyvalent setting, where the hero moves not only

In the Introduction, after reviewing the American criticism on the novel, a summary of Bakhtin's basic theories is presented, in order to show how Bellow is not only a follower but aiso an innovator of the Menippean satire and of carnivalistic literature. Chapter II - The Hero - is concerned with the different aspects of Henderson's character which would place him inside the Menippea's moral-psycological experimentation. The hero's speech. in its turn, is examined by way of polyphony. Chapter $I I I$ - The Quest places the action of the novel inside the most important of the Menippean characteristics, the creation of extraordinary situations to provoke and test a philosophical jdea: the word or the truth. These extraordinary situations are in their tum imbued with a whole series of carnivalistic categories. rituals and images, making ambiguous any monological

interpretation one wishes to give the novel. In the Conclusion we show how all the aspects of the novel are brought together and how the novel acquires a much richer and complex perspective, if examined through the camivalistic vision of the world, which Bellow has conveyed to us.

** Universidade Federal do Paraná

*** BELLOW, S. Henderson the Rain King. New York. Fawcett, 1959. All references and quotations from the book will be taken from this edition, indicated by page numbers cited in parentheses.

'As Marcus KLEIN comments, Henderson "thinks, in Africa, in city metaphors and of city events" (A Discipline of Nobility: Saul Bellow's Fiction. Kenyon Review. 24: 209, Spring 1962).

2 Nebuchadnezzar is the famous king of Caldea who conquered Jerusalem and was punished by God: changed into an ox, for seven years he remained in the woods, after which he recovered his mind and was taken back to the throne 
physically onwards, but also spiritually. As Henderson himself realizes later on, "the world is a mind. Travel is mental travel"' (142). These suggestions, whose implications will develop throughout the action of the novel, are just one of the devices Bellow uses to create an atmosphere for the future foreground of the novel.

If we consider first of all the American setting of Henderson the Rain King, its main raison d'être is to emphasize the "chaotic reality" Henderson lives in, and which serves as a foil to the hero's future adventures in Africa and as a preparation for the hero's quest. It is a much simpler-leveled background - in terms - than Africa, for there is no conflict of interpretation as to its importance among the critics: its "civilized hypocrisy"', together with its bigness, with everybody "working, making, digging, bulldozing, trucking, loading" (25), make it clear that Bellow is, as in other novels 4 , projecting the oppressing and chaotic force of environment as a means of showing its effects on the mind and spirit of his protagonists - and, in this study, on Henderson", for, "in an age of madness, to expect to be untouched by madness is a form of madness" (25).

But America is not just the land where Henderson feels "there" is a curse on" (36); he has a subconscious longing for nature which we can see in the description of his property, where, in "those velvety days of early autumn when the sun is shining on pines and the air has a spice of cold", "the red tuberous begonias grow" (28). This radiance of nature, though, at that moment when he is so antagonistic towards American "facts" that crowd around him, only makes him "crazy with misery" (29).

Later insights into America's urban life come during Henderson's stay in Africa, either in the form of images associated with the activities he is involved with at the moment - such as the darkness that involved him after he has lifted Mummah, the cloud goddess: "After the gust of breeze came deeper darkness, like the pungent

${ }^{3}$ CLAYTON, J.H., Saul Bellow: in Defense of Man. Bloomington, Indiana University Press, 1971 , p.168.

${ }^{4}$ In Mr. Sammler's Planet, for instance, there is an ironic reference to America, "advertised throughout the universe as the most desirable, most exemplary of all nations" (Greenwich, Fawcett, 1971.p.17). For further references to the chaotic force of environment see The Hero.

$5_{\mathrm{M}}$. WIETING, in A Quest for Order: the Novels of Saul Bellow (Ann Arbor, Xerox University Microfilms, 1969. p.152), argues that Henderson is not a victim of the forces of environment, as Bellow's other heroes, because of his financial security and flexibility of movement; Henderson only sees a symbolic reflection, in the setting, of the "disorderly rush" of his life that piles into him "from all sides" and "turns into chaos" (168).

Nevertheless, we are in favour of seeing both environment ane character in a constant interplay one on another. Environment is more than a backcloth or scenery, for it projects the main character while at the same time it is a place of conflict, according to Massaud MOISÉS (Gria Prótico de Ancilise Literória. São Paulo: Cultrix, 1970. p.108). 
heat of the trains when they pass into Grand Central tunnel on a devastated day of August, which is like darkness eternal" (169) - or in the form of flashbacks of his earlier life - such as when he has seen the pink light on the clay wall, with the Amewi, which reminds him of his boyhood back home:

It must have been at least fifty years since I had encountered such a color, and I thought I could remember waking as a tiny boy, alone in a double bed, (. . .); and outside, a white shutter, twelve feet long and covered with the same pink color (87).

Interspersed between the two main settings, we also have glimpses of smaller backgrounds, such as Henderson's "adventures" in France and his fighting in Italy.

The African location of the novel has, in contrast to the American scene, puzzled most of the critics, whose different but complementary interpretations oppose the two backgrounds not only in time and space, but especially in terms of reality-unreality. As a matter of fact, the ambivalent opinion of critics 6 , either emphasizing the fantastic, symbolical or mental, versus the urbanized aspect of the African setting, points to the complexity of its meaning, if we also take into consideration that one of the characteristics of the Menippean satire, as suggested by Bakhtin ${ }^{7}$, is that

\section{"Ihab HASSAN has called it "the magic never-land" (p. 316), Arnold} GOLDMAN a "mythical terrain" (A Remnant to Escape: the American Writer and the Minority Group. In: CUNLIFFE, M. ad. American Liserature Since 1900 . London, Sphere Books, 1975. p.322), Marcus KLEIN "an A frica teeming with people and political intrigue, and with furniture: an Africa urbanized" (p.207), K.M. SWEENEY an "Africa within" (Saul Bellow and the Life to Come. Critical Quarserty, v. 18, n. 1, p. 70, 1976), J. BAUMBACH an "und iscovered Africa of the spirit" (The Landscape of Nightmare: Studies in the Contemporary American Novel. New York, the University Press, 1970. p.35), D.D. GALLOWAY a "symbolic A frica" (The Absurd Hero in American Fiction. Austin. University of Texas Press. 1974. p.111), J.H. CLAYTON a "mental. metropolitan Africa" (p.252), M. Gilbert PORTER "a symbolic Africa of the soul" (p.129), R.G. DAVIS a "purely fictive Africa" (p. 129), M. BOULTON "as much a territory of the mind as a geographical area" (The Anatomy of the Novel. London, Routledge \& K. Paul, 1975. p.136), while for D. HEYNEY the novel has a "rather fantastic surface (...) built upon Bellow's memory of books" but which conceals and suggests "a kind of anthropological concern which is crucial to the novel, and to Bellow himself' (p.80).

7BAKHTIN.M. Problems of Dostcer:dy's Poetics. Ann Arbor: Ardis, 197.3 
the menippea often includes elements of social utopia which are introduced in the form of dreams or journeys to unknown lands; (. . .) The utopian element combines organically with all the other elements of the genre.

One sees how the almost antagonistic elements become fused when considered as part of this Menippean characteristic, for, in Henderson the Rain King, both forms of the dream and the journey 8 to unknown or nonexistent lands appear, intimately linked: Africa assumes not only the double role of being an unknown land, a Utopic place 9 where Henderson can find a simplified and therefore more perfect civilization than the one he was born into, but also that his experiences there seem to him to have happened almost as if in a dream. Moreover, Africa provides the hero with a chance of projecting his character - the good side of his character, in contrast to his American background, which helped to show off his seamy side through the conflicts and experiences he is involved in. The dream element 10 of the menippea is actually an inherent part of the whole experience, and referred to by Henderson before starting the tale of his adventures in Africa. He explains to us (the readers) that "living proof of something of the highest importance has been presented to me so I am obliged to communicate it ${ }^{11}$. And not the least of the dif-

${ }^{8}$ R. BOURNEUF and R. OUELLET give a further dimension to this journey in novels, when they comment that "le voyage donne a ces romans leur sujet et leur principe d'unité, la matière des péripéties, le rythme; par lui se révèlent ou s'accomplissent les personnages et, par delà ces aventures grotesques ou épiques, l'auteur songe à un autre voyage, celui de l'homme pendant son existence. Loin d'ètre indif férent, l'espace dans un roman s'exprime donc dans des formes et revêt des sens multiples jusqu'à constituer parfois la raison d'être de l'oeuvre" ( $L$ 'Univers du Roman. Paris : Presses Universitaires de France, 1975. p.99-100).

${ }^{9}$ As explained by M.H. ABRAMS (p.177), the title [Utopia, by Sir Thomas Moore] plays on two Greek words, "outopia" (no place) and "eutopia" (good place); and the Utopia has come to signify the class of fiction which represents an ideal political state and way of life. (. . .) Most Utopias since Plato's, beginning with that of Sir Thomas More, represent their ideal place under the fiction of a distant country reached by some ventu resome traveler."

${ }^{10}$ Brigitte SCHEER -SCHÄZLER comments that "to counteract all accusation of improbability Bellow has introduced the possibility of seeing the whole book as the rendering of a dream" (Saul Bellow. New York : F. Ungar, 1973. p.86).

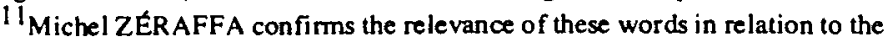
narrator's message, by remarking that " qui frappe surtout, dans les romans des XVIle. et XVIIle. siècles, c'est que la plupar des auteurs disent en substance: Je vais vous présenter une fiction, mais ce que je vais exprimer est important; il s'agit de la vie, d'une société, de personnes vraies et de problèmes réels" (La personne du narrateur dans la littérature romanesque. In: MEYER SON, I. dir. Problemes de la Personne. Paris : Mouton, 1973.p.274). 
ficulties is that it happened as in a dream" (22).

Tzvetan Todorov, commenting on the concept of the fantastic, which he defines in relation to the concepts of the real and of the imaginary 12 , cites an example from Olga Reimann which could explain particularly well Henderson's dilemma in himself believing in the experiences he has had:

Le héros sent continuellement et distinctement la contradiction entre les deux mondes. celui du réel et celui du fantastique, et lui-mème est étonné devant les choses extraordinaires qui l'entourent. 13

The dream element is further stressed when Henderson arrives in Africa, by plane, for the continent from the air "looked like the ancient bed of mankind. And at a height of three miles, sitting above the clouds, I felt like an airborne seed" (39). And Henderson dreams "down at the clouds", just as a child he had dreamed "up at them" (39).

Now the Utopian element appears, for Henderson, after leaving Charlie and his wife, starts a trip on foot with his guide Romilayu "beyond geography" (50); this is also emphasized when Romilayu "for days and days" leads Henderson "through villages, over mountain trails, and into deserts, far, far out" (41). The new region they enter, with "no human footprints", makes Henderson feel he is "entering the past - the real past, (...). The prehuman past"14, where all is "simplified and splendid" (42). These Utopian elements are supported by references to Africa as an unknown land, for the Hinchagara plateau which they reach later on is a territory that "has never been well mapped" (43). The Arnewi village, to which they come, looks like a "picture" (43) to Henderson and in its oldness, "like the original place. It must be older than the city of Ur" (44) 15 .

12 TODOROV. T. Introduction à la Littérature Fantastique. Paris : Seuil, 1970. p.29-30.

1316id., p. 30

14 A similar reference to Africa as "the place where the human species got its start" is made by George Swiebel to Charlie Citrine, the hero of Hionbold's Gift (p.432).

15 Another reference to an original world is made by Charlie Citrine, when he mentions that "one of Humboldt's themes was the perennial human feeling that there was an original world, a home-world, which was lost" (p.23), thus showing how Bellow's concern with this question appears under different circumstances in his novels. 
In this "simplified" place, Henderson is sure he "had gone clean out of the world, for, as is common knowledge, the world is complex" (48), echoing Thoreau. Besides, Henderson was so struck by the very "antiquity of the olace" that he was sure he "had got into someplace new" (48). The parallel with Egypt (referred to in relation with Moses) is again mentioned, adding a Biblical dimension to the plague of trogs which curses the Arnewi, and corroborating Henderson's "feeling of antiquity" the place had given him (54). Thus, the Utopic element of a place lost in space and time is always being reinforced, either by mentioning its antiquity through Biblical or mythical elements, or through the fact that it is an unknown place, inaccessible up to now, to human beings.

As Henderson further comments, "here we were in the farthest African mountains - damn it, they couldn't be much farther! -"(76) and the fascination he feels for place and situation, as a guest of the Arnewi, is beautifully conveyed to us during the pageant presented to him in the "bluish moonlight":

Thus I realized as the night and the dancing wore on that this was enchantment. This was poetry, which I should allow to reach me, to penetrate the practical task of demolishing the frogs in the cistern. And what I had felt when I first laid eyes on the thatched roofs while descending the bed of the river, that they were so ancient, amounted to this same thing - poetry, enchantment (85).

The pink color that he detects on the white clay wall beside his hut, at daybreak, brings him again into a dream state: "Some powerful magnificence, not human, in other words, seemed under me." The pink light "was similar to flying over the white points of the sea at ten thousand feet as the sun begins to rise. It must have been at least fifty years since I had encountered such a color" (87). This mild hue makes Henderson say to himself once more:

I knew this place was of old". Meaning, I had sensed from the first that I might find things here which were of old, which I saw when I was still innocent and have longed for ever since, for all my life - and without 
This passage reminds us of the golden age of innocence of Utopia, in relation to Africa, and the fact that Henderson has "lost count of the days" (43) as, probably, "the world was glad to lose track of me" also adds to the distance in time and space which is part of Utopias.

Other associations of Africa with an inaccessible place are made later, when Henderson and Romilayu, heading towards the Wariri tribe, have to cross a desert and then high mountains, and the sterility of the landscape adds a feeling of lonesomeness and danger to the hiddenness of the place. Rocks and stones dominate the landscape, contributing, with their very aspect, to the remoteness and antiquity of Henderson's surroundings. As Gaston Bachelard ${ }^{16}$ comments,

les rochers ce sont (. . ) des images fondamentales. (...) Ces êtres d'univers, (. . .) sont aussi des êtres de la préhistoire de notre imagination (...)

L'amas des roches a toutes les menaces d'un ciel d'orage.

These lines seem to materialize again in Bellow's subtle description of the mountains, those "domelike white rocks (...) as white as chinaware" (99), which Henderson encounters after having walked for nine or ten days, without seeing any human beings. With their "crumbled peaks and prehistoric spines" (99), they seem to acquire human form in the figure of the standing Wariri herdsman who arose before them "in a leather apron, holding a twisted stick, and although he did nothing else he looked dangerous" (99). Something in his figure strikes Henderson as Biblical, thus establishing the connection rock/man in the words "prehistoric" and "domelike" applied to rocks, and "Biblical" applied to the herdsman; in the same way, the connection "spine", applied to the mountains as it also applies to a human being, is established. The rocks have suddenly 1971. p. 184.

16 BACHELARD. G. La Terre er les Réveries de la Vodemé. Paris: I Coni. 
become human ${ }^{17}$, like in a dream situation, because it is likely that Henderson wants to see a human being, after all these days and so the mountains suddenly become anthropomorphic for him, in the figure of the Wariri herdsman. As Bachelard further says, "le paysage devient un charactere" 18 . Bellow thus skillfully merges the landscape with the human figure and with Henderson's longing, and, in the same way that rocks seem "menacing" for Bachelard, the Wariri herdsman looks dangerous to Henderson. When the herdsman shows both men the way to go, Henderson thinks: "thus old-time travelers must have been directed" (99), linking once more the antiquity of the place with that of the natives.

Toiling upward among the rocks, these elemental white stones make Henderson suspicious, for they seem to him as inimicall9 as the Wariri herdsman - the hostile and sterile landscape stressing the enmity of the African man - and as the three tribesmen who aimed guns at him and at Romilayu, once more expressing the defiance in nature at the intrusion of strangers: dream has now become a nightmarish reality, Utopia has become a Dystopia, a very unpleasant imaginary world, and this nightmarish reality makes no sense to Henderson in the same way that the stones look "senseless" to him:

The way grew more and more stony (...) there were these jumbled white stones that looked as if they had been combed out by an ignorant hand from the elements that make least sense. There must be stupid portions of heaven, too, and these had rolled straight down from it. (...) the word calcareous seemed to fit them. (...) Now they were ultra-dry but filled with little caves from which cooler air was exhaled - (...). The cave mouths were open and there was this coarse and

${ }^{17}$ Bachelard muses on the same theme: "Pourquoi, (. . .) le rocher tiendrait-il plus wlidement sa forme humaine, sa forme animale que le nuage qui passe? N'est-ce point une forme subjectivement première, formée précisément dans la volonté de voir, dans la volonté de voir quelque chose, mieux enfin dans la volonté de voir quelqu'un. La réalité est faite pour 'fixer' nos rèves (...)

A propos du rocher, ecoutons alors la discussion de l'imagination et de la perception raisonnable. La raison répè te: 'C'est un rocher', mais l'imagination suggère sans cesse mille autres noms: elle parle le paysage, elle commande sans fin des changements de décor" (p.185).

18 lbid., p.71.

${ }^{19}$ As Bachelard explains it, "le rocher (. . .) nous apprend à vivre le réel dans toutes ses profondeurs et ses prolixités.

Mais la littérature du défi doit naturellement être associée à la littérature de la peur. 1.) La fonction du rocher est de mettre une terreur dans le paysage" (p.191). 
clumsy gnarled white stone $(100)$.

This elemental image of stones combed out by an "ignorant hand" parallels the "elementary cunning" (100) of the three tribesmen waiting for them in an ambush, giving Henderson again the satisfaction of being in contact with the beginning of civilization 20. (Much later, Henderson is going to refer again to these boulders, to this same irrationality of landscape, for these boulders were "like gross objects combed down from above by an ignorant force" (246): it is during the lion hunt with King Dahfu, this time making us associate the ignorant force with Dahfu's death by the lion, through the Bunam's premeditated trap).

In his first interview with King Dahfu, Henderson is told that "we have preferred a seclusion, for many generations now, and we are beautifully well hidden in these mountains" (132), while further on the king also comments, "I told you how excited I have been since the announcement of your appearance from the outside world" (140), stressing once more the fact that Henderson belongs to a world far away from the Wariri's self-chosen hiddenness.

The dream element of the menippea is further stressed when Henderson's dream state is again brought into focus: while sitting beside the king during the rain-making festivities, he tells us "believe me, I felt like a dreamer, and that's no lie" (145). He says this after mentioning to us that the examiner and the wrinkled old black leather fellow who had sent him and Romilayu into an ambush, were on the king's left side, together with Horko. Henderson further mentions that this black-leather fellow, who had arisen out of the white rocks, was "like the man met by Joseph. Who sent Joseph over to Dothan. Then the brothers saw Joseph and said, 'Behold, the dreamer cometh." " $(145)^{21}$. By a striking coincidence, this same passage is quoted by Scholes and Kellogg22 again in reference to dreams, thus reinforcing the use of dreams as "supernatural machinery to

20 This also corroborates Bachelard's quoting D.H. Lawrence that "on comprend facilement que les hommes adorent les piertes. Ce n'est pas la pierre. C"est le mystere de la terre. puissante et préhumaine, qui montre a force" (p.189).

${ }^{21} \mathrm{Cf}$. Henderson the Rain King: "Something about his figure struck me as Biblical, and in particular he made me think of the man whom Joseph met when he went to look for his brothers. and who directed him along toward Dothan. My belief is that this man in the Bible must have been an angel and certainly knew the brothers were going to throw Joseph into the pit. But he sent him on nevertheless." (99)

${ }^{22}$ SCHOLES, R. \& KELLOGG, R. The Nature of Narrative. London : Oxford Univ. Press. 1971. p. 176. 
reveal mental processes":

\begin{abstract}
Dreams are frequently used in early narrative for such purposes, and are wonderfully suited to characterization which is poised between the mythic and the mimetic. Dreams can be referred to the divinities which shape our ends, or to the mental processes of human beings. Joseph's brethern assume his dreams are merely a reflection of his ambitions, and there is a considerable hostility and fear in their cry, "Behold, this dreamer cometh": but events prove the dreams divinely inspired and not merely reflections of Joseph's overweening pride.
\end{abstract}

(An analogy can thus be established between Joseph's dreams which were divinely inspired and Henderson's dreams of regeneration - the forgiveness of sins - which were also inspired: Henderson feels like Joseph, like a dreamer, in spite of the hostile surroundings).

Henderson also lifts the cloud goddess Mummah, with his cheek against her wooden bosom, "with the close pleasure you experience in a dream" (163). Then, bravely and stoically meeting his new function as the Sungo, or rain king, Henderson has the same "strange, many-figured, calcareous white stone" (167) under his feet, which he had seen on his arrival at the Wariri. Standing there on these white limestones, before he is prepared by the examiner and by the generaless to assume his role as Sungo, he muses: "that stone, too, was a world of its own, or more than a single world, world within world, in a dreaming series" (167), thus projecting the inner world of dream against the outer world of reality23. It seems as if Bellow does not want us to forget the close association of the words real/unreal, true/fantastic 24 in reference to time and space, in his continual mentioning of the remoteness and antiquity of the location, with hints not only of a lost paradise but also of the wildness and primitiveness of Africa.

${ }^{23} \mathrm{G}$. BACHELARD makes a similar remark about the sand-stone: "Le grès est la pierre la plus a musante et la plus étrangement pétrie qu'il y ait (. . .). Pas d'apparence qu 'il ne prenne. pas de caprice qu'il n'ait, pas de rêves qu'il ne réalise; il a toutes les figures, il fait toutes les grimaces. Il semble animé d'une âme multiple" (p.187).

24 As Richard CHASE comments, "Bellow's fertile sense of the ever possible conversion of reality and imagination, fact and legend, into each other is the source of the richncss and significance of his writing" (The Adventures of Saul Bellow: Progress of a Novelist. Comonentary, v.27, p.327, April 1959). 
Other references to the hiddenness of the place Henderson was in are made in Dahfu's apartment, "in the midst of darkness, in a small room in a hidden fold near the equator" (182), where Henderson has found dignified behavior. The "strangeness" (182) of this situation also becomes apparent through the king's "exotic and specially accented way" (194) of talking.

There is even "a certain amount of Alice-in-Wonderland jollity" (203) in Dahfu's palace yard, while the unreality of a Schlaraffenland atmosphere comes to our minds when, on a hot afternoon, Henderson feels the air to be "dreamy with the heat and the mountains in places (. . .) like mollasses candy 25 , yellow, brittle, cellular, cavey, scorched" (205) against which is contrasted the solidity of the "stripes of shadow" in the sun.

Thus, in a constant interchange between mentioning the unknown and the Utopic, the strangeness and dreamlike quality of Henderson's experience, the novel moves on. As Todorov aptly observes, "'J'en viens presque à croire': voilà la formule qui résume l'esprit du fantastique. La foi absolue comme l'incrédulité totale nous mèneraient hors du fantastique; c'est l'hésitation qui lui donne vie" 26 . It is this duality, so apparent throughout the novel, which makes us wonder, and hesitate, like Henderson himself, between belief and disbelief, for "le fantastique implique la fiction" 27.

The dream element is stressed again when Henderson is lying on the ground in the lion's den, hearing Dahfu preach to him. As he tells us, "if this body, if this flesh of mine were only a dream, then there might be some hope of awakening. That was what I thought as I lay there smarting." (223). And, in a letter to his wife Lily, Henderson confirms the dream-like situation he was in, by writing:

"The flight here was spectacular."

Like hovering all the way inside a jewel.

(. . .) For me the entire experience has been similar to a dream. (236)

25 Bellow's association of the mountains looking like molasses candy to a child's dream land is explained by Bachelard as belonging to the "images de la fineswe materielle". caused by "les arts du sucre" - (Henderson even mentions the mountains look "as if they might be bad for the teeth" because of the sugar (205) - and Bachelard quotes Michelet's description of the Alp as "le glaciet candi" (p.86).

${ }^{26}$ TODOROV.T. p. 35

${ }^{27}$ Ibid., p. 65 
He also mentions to her that he has asked Romilayu to show him "the uncivilized parts of Africa" and that he was "off the beaten track" (236); for "here they don't know what tourists are, and therefore I'm not a tourist (...) This is a very primitive part of the world. Even the rocks look primitive" (237) in this way stressing once again the strangeness of the adventure. A little before writing this letter, Henderson has also commented to Romilayu about his children: "Do you worry about them? It's a wild continent still, no two ways about that" (234) thus emphasizing one more time the untamed, violent and outlandish aspect of this Africa about which Anthony Burgess muses: "Henderson leaves America for an Africa which is not on any map: it is perhaps the dark continent of his own unconscious mind" 28 .

When running away from the Wariri with Romilayu, Henderson mentions again the inaccessibility and remoteness of the place: "Thirty miles of terrain opened before us, the path of our flight" (273). It is a "no man's land" (269) which they have to cross, "without food or a gun" (269) and it takes them ten days to cross this wilderness back to civilization, again stressing the complete lack of connection with the known world, which is the distinctive mark of Utopias.

Depiction of foreign and strange ceremonies are also abundant, intensifying the feeling of the exotic setting:

Shaven-headed women flitted near us, shrill and nervous, and a gaudy crowd had collected, just as on the day of the rain ceremony - drummers, men in paint, shells, and feathers, and buglers who blew some practice blasts (244).

And, the other way round, the Wariri themselves did not want Henderson's "whereabouts to be known to the world" (263) by bringing Romilayu with the letter to Lily back to their village.

At the end of his experience, back into "geographical" Baventai, Henderson sleeps and has dreams, but is afraid "those were not dreams, but hallucinations" (275), for he lay feverish on a cot "in somebody's house". With this affirmation, he brings together the two statements at the beginning and at the end of his trip, that "it happened as in a dream". And, back in his homebound plane, Hen-

${ }^{28}$ BURGESS. A. The Novel Now. London: Faber \& Faber, 1972 p. 199. 
derson cannot understand how other passengers were reading: "How can you sit in a plane and be so indifferent? Of course, they weren't coming from mid-Africa like me 29 ; they weren't discontinuous with civilization" (279). Once more we hesitate whether the whole experience was nothing more than a dream, when Henderson tells the stewardess "You see, I got sick in Africa and had a delirium and lost count of time. When you go in deep you run that risk, you know that, don't you, kid?" (280) to account for the fact that he had lost count of time, because he was delirious.

There are even references to Henderson being out of his mind, that the whole experience was a mental deceit, such as when he is plotting his flight from the tomb where he is being kept, in a room adjoining the dead king Dahfu:

So when night began. I sat plotting, concentrat ing my ideas and trying to protect their clarity from my fever, which increased every afternoon and rose far into the night. I had to fight against delirium, as my condition was aggravated by the suffocation of the tomb and the hours of vigil I spent at the chink in the wall straining one eye at a time toward the dead figure of the king. Sometimes I imagined that I could see some of the features under the flap of the cowl. But this was more mental. . mental deceit: dream. My head was out of order, as I realized even then I was most aware of it at night, under the influence of fever, when mountains and idols and cattle and lions, and gross black women. the amazons, and the face of the king and the thatch of the hopo visited my mind, coming and going unannounced (270-1).

Therefore, all these different allusions to remoteness, to the

${ }^{29}$ The relation of Henderson w Harry in Hemingway's The Snows of Küimanjaro in this passage is obvious: Edmund Wilson comments that at the end of Hemingway's story. "the reader is made to real ize that what had seemed to be an escape by plane, with the sick man looking down on Africa, is only the dream of a dying man" (The Wound and the Bow'. London, Methuen, 1961 . p.214), while in Henderson the Rain King, in an inversion of situation, the $A$ frica Henderson looks down on is the dream of a man looking for salvation. flecing from death and chaos. Henderson is going to come back victorious to civilization, in contrast to Harry who dies on the hunting expedition to Africa. "out of which he has foiled to get what he had hoped" (Wilson, E., p. 214).

One could also mention Leslie FIEDLER's opinion abour Henderson the Rain King here, for whom Hermingway is "evoked by a hulking giant of a protagon ist whose initials are E.H. " ( . .); and for all its mannered irony and outright burlesque, Bellow's book, 100. seems - especialy now - a memoir and a tribute" (Waiting for the End. England, Pelican Books. 1967. p. 109). 
heart of the dark and unknown continent with its Conradian nuances, to a Utopic, fantastic, strange, dream-like landscape, remind us of the many-levelled approach Bellow has given to the background of the novel. It is the recurrence of these devices that point to "meaning by association" 30 , for the change of background provides Henderson exactly with a means of adjusting himself to the essential facts of life - simplicity - first, and later, to life's more complex and demanding features. In this way, the African background would also serve as an "example", which is "the point of the invented background of all utopian novels"' 31 .

Before moving on to discussing the "real" Africa, we still have to examine the relationship that this fantastic Africa has in reference to time, as another aspect of the hero's adventures taking place not only in an Africa lost in space but also in time, as a counterpoint to an America set in both. Todorov points out again, in relation to texts of fantastic literature 32 , that

le monde physique et le monde spirituel s'interpénètrent; leurs catégories fondamentales se trouvent modifiées en conséquence. Le temps et l'espace du monde surnaturel, (...) ne sont pas le temps et l'espace de la vie quotidienne. Le temps semble ici suspendu, il se prolonge bien au-delà de ce qu'on croit possible.

Bakhtin confirms these words in relation to the Menippean satire when he says that Dostoevsky's words

"... It all happened as it always does in a dream, when you leap over space and time, over the laws of existence and reason, stopping only on those points which causee your heart to dream." (X, 429)

are "in essence a completely accurate characterization of the compo-

${ }^{30}$ WETHERILL, P.M. The Literary Text: An examination of Critical Methods. Oxford: Blackwell, 1974. p. 180.

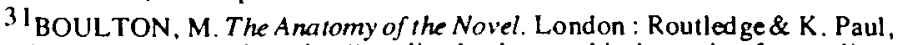
1975. p.129. She also mentions that "an alien background is the setting for an alienated man" (p.137).

32TODOROV.T... .124 
sitional method of the construction of the fantastical menippea".3.3.

The time element then, contributes to the dream atmosphere of the novel on different occasions, such as when Henderson tells us, on that fiery dawn with the Amewi, "I became convinced (and still am convinced) that things, the object-world itself, gave me a kind of go-ahead sign" (86); or when he comments on the effect that Dahfu's conversation had on him: "I gripped my legs through the green silk trousers of the Sungo and I am sure I must have been demented at that time. Slightly. I was really sent, and I mean it" (182). If these two quotations convey to us the leap in time and space from the past of the narrated events to the present of the narrative, in other instances time is either contracted or expanded, in order to "cause our heart to dream": as Henderson remarks in his letter to Lily, "this experience in Africa has been tremendous. It has been tough, it has been perilous, it has been something! But I've matured twenty years in twenty days" (237) - thus connecting it also slightly with Rip Van Winkle's story 34.

Time seems to slow down again when Henderson describes to us the danger he and the king were subjected to, waiting for the lion:

For the count of about twenty heartbeats I only partly knew where I was or what was happening. Mainly I kept a fixed watch on the king. ready to hurl myself down if he should fall. Then, at the very doors of consciousness, there was a snarl (...) (257).

In this manner, time projects again the partial unconsciousness of the hero in relation to what was happening and to where he was, while at the end of his experience, time seems to be counted again according to our standards of reality, for Henderson asks Romilayu, "Have we been in this town a full month?" (270), to which the guide answers affirmatively. This bit of information is further stressed when Henderson starts counting the days of the week, back to civilization: "This was Wednesday. On Thursday we flew to Athens. (. . .) On Friday I got to Rome. (. . .) On Saturday we flew again by way of Paris and London, which was the only arrangement I could make" (278-9).

${ }^{33}$ BAKHTIN. M Problems. .. p. 12.

${ }^{34}$ Several references to Rip Van Winkle are made in Humboldr's Gift. 
Therefore, if Bellow inserts himself as a follower of the Menippean satire already with Henderson's journey to an unknown land, with surreal dimensions, he also counterbalances this characteristic with a detailed description of the African landscape, bringing the trip back again from the fantastic and distant in space and time to the real and, by the author, well-known territory. As Irving Malin has observed in relation to the African setting of the novel ${ }^{35}$,

The fantasy which occurred at crucial points in the early novels is completely in the foreground. The various rituals, gestures, and situations are, in effect. "waking dreams." "A frica" is the dark continent of the mind - anything can happen here: a dwarf can sit on a goddess; a man can "become" a lion: a ruler can speak in Reichian terms. Reality and fantasy are turned upside-down: fantasy is true reality; reality (of, say, Connecticut) is unreal. Thus it is dangerous to ask all the time about Henderon: what does it mean? Fantasy implies intimations of meaning which cannot be "logically" grasped - as dreams are never really understood

But it is this fantastic Africa which we are going to leave now, in order to examine the "real" Africa. And even if this "real" Africa is a "piece of composition" 36 , because Bellow knows Africa through books, he has made a "map" of this fictitious Africa, in the same way as there is a map of real Africa, and of this "fictitious site" he knows "all the accessories" as though he had "lived and wandered there" 37 . It is truly admirable, for this reason, that the author could provide us with a work of his imagination which is poetically and physically real - through the details he furnishes us with - while at the same time he makes us aware that he did not aim at identifying his Africa either with the Africa of antiquity or of modern times, for it is actually a parody of nineteenth and twentieth century literature on Africa that we become conscious of, in the end.

Bellow's depiction of real Africa, then, reflects credit on his depiction of symbolic Africa, in the same manner that the symbolic background grows out of the real African landscape. As the "selec-

35 MALIN, I. Saul Bellow's Fiction. Carbondale : Southem Illinois University Press, 1969. p.129-30. p. 299

${ }^{36}$ A LLOT, M. Novelists on the Novel. London: Routledge \& K. Paul, 1973.

${ }^{37}$ Ibid.. p.30I. 
tion of telling detail" 38 adds to Bellow's creating a believable Africa, the first picture we are provided with of this geographical Africa is of Henderson, with Charlie and his wife, camping near a lake:

The water here was very soft, with reeds and roots rotted, and there were crabs in the sand. The crocodiles boated around in the lilies, and when they opened their mouths they made me realize how hot a damp creature can be inside. The birds went into their jaws and cleaned their teeth. (. .) On the trees grew a feather-like bloom and the papyrus reeds began to remind me of funeral plumes (40).

Besides, Bellow's pictures of Africa do not limit themselves to describing the land, but also the natives; first in a general way - "tall Negro cowherds came up to us with their greased curls and their deep lips. I had never seen men who looked so wild" (41) - then in a more particular way, as when describing the guide Romilayu: his loose skin, a bush of dusty hair which spread out like a dwarf pine, cheeks cut with old tribal scars and mutilated ears, plus an Abyssinian nose, remind Henderson that "the scars and mutilations showed that he had been born a pagan, but somewhere along the way he had been converted, and now he said his prayers every evening" (42). The Amewi and their village are also minutely described, providing us with a picturesque image of their place:

Then we sighted the Arnewi village, and we saw the circular roofs which rose to a point I knew they were just thatch and must be brittle, porous, and light: they seemed like feathers, and yet heavy - like heavy feathers. From these coverings smoke went up into the silent radiance. Also an inanimate glitter came off the ancient thatch (43)

Henderson also observes "that the coloring of these people was very original and that the dark was more deeply bumt in about the eyes

38 ALLOT. M.. p. 304. 
whereas the palms of their hands were the color of freshly washed granite" (47). Everything is strange and new to him, and in the same detailed manner are the ceremonies, processions, fights and dances described.

In conclusion to this first part of the analysis of Henderson the Rain King, with the examination of this "partly real, partly dreamcountry" 39 through the quoting of several passages which project the polyvalent setting, we have to keep in mind that both places, America and Africa, are not strictly separated in the narrative process. As already mentioned, Bellow's use of the stream-of-consciousness technique keeps both settings in the foreground, so to say, for, in the same way that we have suggestive hints of Africa while Henderson is still in America, when in Africa the situation is reversed and we are reminded all the time of Henderson's American environment.

Thus, having discussed first of all Henderson's American setting, as the most denotative background, we have then considered the Utopic Africa which Henderson joumeys into - as befits this most important characteristic of the menippea: the hero's wandering through unknown fantasy lands and being placed in extraordinary situations ${ }^{40}$. Then, after stressing how the time element also contributes to establish the ambiguity of the "dream situation" Henderson is in, we have shown how the details Bellow gives us of a geographical Africa bring it back to our credibility. In this way, the triple function of the African background has been conveyed as a relevant element in the structure of the novel and particularly of the menippea: as a real setting, where the action takes place; but treated so intensely that the details of scenery also become part of a Utopian landscape, lost in time and space, making the background become more one of "atmosphere" than of "locality" 41 , but of which the author knows the map; and, finally, the place in which Henderson's character will be further revealed and transformed, where conflicts and incidents will take place, either external or internal, thus enlarging the original Menippean characteristic with a further dimension.

\footnotetext{
39. Ibid., p. 302.

${ }^{40}$ B A KHTIN, M. Problemss. ., p.94. See also Introduction.

$41_{\text {BOULTON, M. p. } 139 .}$
} 


\section{BIBLIOGRAPHICAL REFERENCES}

1 ABRAMS, MH. A Glossary of Literary Terms. 3.ed. New York: Holt. Rinehart and Winston. 1971.193 pp.

2 ALLOT, M. Norelists on the Novel. London : Routledge \& Kegan Paul. 1973. $336 \mathrm{p}$.

3 BACHELARD. G. La Terre et les Rêveries de la Volonté Paris: J Corti, 1971. 407 p.

4 Bakhtin, M. Problems of Dostces'sky's Poetics. Trans. R. W. Rotsel Ann Arbor: Ardis, 1973. 249 p.

5 B AUMBACH, J. The Landscape of Nightmare: Studies in the Contemporary American Novel. New York: the University Press, 1970. $173 \mathrm{p}$.

6 BELLOW.S. Henderson the Rain King. New York: Fawcett, 1959 $286 \mathrm{p}$.

7 BOULTON, M. The Anatomy of the Novel London : Routledge \& K Paul. 1975. 189 p.

8 BOURNEUF, R. and OUELLET, R. L'Univers du Roman Paris: Presses Universitaires de France. 1975. 248 p.

9 BURGESS, A. The Novel Now. New ed London : Faber \& Faber, 1972. $229 \mathrm{p}$.

10 CHASE, R. The Adventures of Saul Bellow: Progress of a Novelist. Commentary, 27: 323-30. April 1959.

11 CLAYTON. J. Saul Bellow in Defense of Man Bloomington: Indiana University Press, 1971278 p.

12 DAVIS, R.G. The American Individualist Tradition: Bellow and Styron. In: BALAKIAN, N and SIMMONS, C., eds. The Creative Present. Garden City : Doubleday, 1963. p.111-41

13 FIEDLER. L. Waiting for the End. England : Pelican Books, 1967 $284 \mathrm{p}$.

14 GALLOWAY, D. The Absurd Hero in American Fiction. Rev. ed. Austin: University of Texas Press, 1974. 274 p.

15 GOLDMAN, A. A Remnant to Escape: The American Writer and the Minority Group. In: CUNLIFFE, $M$ ed. American Literature Since 1900. London: Sphere Books, 1975, p.312-43.

16 HASSAN. I. Radical Innocence: Studies in the contemporary American 
Novel. Princeton: the University Press. 1973. 362 p.

17 HEINEY, D. Bellow as European. In: ZYLA, W.T \& A YCOCK, W. M. eds. Mode'n American Fiction: Insights and Foreign Lights Lubbock: Texas Tech University, 1972. p.77-88.

18 KLEIN, M. A Discipline of Nobility: Saul Bellow's Fiction. Kenyon Review, v.24, p.203-26, Spring 1962.

19 MALIN, I. Saul Bellow's Fiction. Carbondale: Southern Illinois Univ Press, 1969. $179 \mathrm{p}$

20 MOISÉS, M. Guia Prâtico de Análisè Literárica. Sāo Paulo: Cultrix. 1970. $284 \mathrm{p}$.

21 PORTER, M.G. Whence the Power? The Artistry and Humanity of Sand Bellow. Columbia : Univ of Missouri Press, 1974. 209 p.

22 SCHEER-SCHÄZLER. B. Salu Bellow. New York : F. Ungar, 1973. $250 \mathrm{p}$.

23 SCHOLES, R and KELLOGG, R. The Nature of Narrative. London : Oxford Univ. Press, 1971. $326 \mathrm{p}$.

24 SWEENEY, K Mc. Saul Bellow and the Life to Come. Critical Quarterly, v.18, n.1, p.67-72, 1976.

25 TODOROV. T. Introduction à la Littérature Fantastique Paris : Seuil. 1970. $189 \mathrm{p}$.

26 WETHERILL, P.M. The Literary Texr: An Examination of Critical Methods. Oxford: Blackwell, $1974331 \mathrm{p}$.

27 WIETING, M. A Quest for Order: the Novels of Saul Bellow Ann Arbor: Xerox Univ. Microfilms, 1969228 p Dissertation.

28 WILSON, E. The Wound and the Bow. Rev. ed. London : Methuen, 1961. 264 p.

29 ZÉRAFFA, M. La Personne du narrateur dans la littérature romanesque. In: MEYERSON, I. dir. Problèmes de la Personne. Paris : Mouton, 1973. p.273-79. 